Andreja Retelj

Univerza v Ljubljani

Filozofska fakulteta

andreja.retelj@ff.uni-lj.si
UDK 811.112.2’373:37.091.3(497.4)

DOI: $10.4312 /$ vestnik.7.255-266

\title{
POUČEVANJE STRATEGIJ ZA UČENJE BESEDIŠČA PRI POUKU NEMŠČINE V SLOVENSKIH GIMNAZIJAH
}

\section{UVOD}

Številne raziskave (npr. Oxford 2002, Lee 2003, Cohen 2007, Prichard 2008) kažejo, da sta poznavanje in raba učnih strategij eden izmed pomembnih dejavnikov za doseganje uspeha pri učenju. O pomembni vlogi učnih strategij za učenje jezikov pričajo številni poskusi taksonomizacij učnih strategij za učenje jezikov, ki so nastajali po letu 1970 in so poskušali zaobjeti različne vidike učenja in z njim povezane učne strategije (glej O'Malley in Chamot 1990). Za ponazoritev omenjamo le nekaj najbolj poznanih taksonomij učnih strategij. O'Malley s sodelavci (1985) ločuje med metakognitivnimi, kognitivnimi in socioafektivnimi učnimi strategijami. Rubin (1987) ugotavlja, da na učenje jezikov vplivajo trije tipi strategij, in sicer učne strategije, ki obsegajo kognitivne in metakognitivne strategije, komunikacijske strategije in socialne strategije. Ellis and Sinclair (1989) ločujeta metakognitivne in kognitivne učne strategije. Eno danes najbolj poznanih in uporabljenih taksonomij je izdelala Oxfordova (1990), ki učne strategije deli na direktne in indirektne. Te nadalje loči na šest skupin. K direktnim strategijam uvršča spominske, kognitivne in kompenzacijske strategije, $\mathrm{k}$ indirektnim pa metakognitivne, afektivne in socialne strategije. Sternova taksonomija (1992) obsega pet kategorij učnih strategij, to so strategije načrtovanja, kognitivne strategije, komunikativno-izkustvene strategije, interpersonalne in afektivne strategije.

Iz teoretičnih okvirov učnih strategij za učenje jezika so izhajali tudi strokovnjaki, ki so se ukvarjali eksplicitno s strategijami za učenje besedišča. Besedišče kot osnovno komunikacijsko sredstvo za sporazumevanje $\mathrm{v}$ tujem jeziku učencem pogosto povzroča težave. Ravno zaradi velike količine besedišča, ki se ga je treba naučiti, da lahko uspešno obvladujemo različne jezikovne situacije in zaradi kompleksnosti, ki jo izzove pravilna raba besedišča, je učenje besedišča zahteven in dolgotrajen proces. Poučevanje besedišča pa ima pri tem pomembno vlogo.

Tseng, Dörnyei in Schmitt (2006) povzemajo ugotovitve številnih avtorjev in ugotavljajo, da učenci, ki uporabljajo učne strategije za učenje, dosegajo boljše rezultate, so učinkovitejši pri učenju, so bolj iznajdljivi in lažje usvajajo jezik kot tisti učenci, ki strategij ne uporabljajo. Chamot (2009) ugotavlja, da učenci za učenje besedišča uporabljajo celo več 
strategij kot za učenje drugih jezikovnih prvin. Schmitt (1997) je prepričan, da je eden izmed vzrokov za to tudi zavedanje o pomembnosti poznavanja besedišča. Paribakht in Wesche (1997) ugotavljata tesno prepletenost in vzajemnost med poznavanjem besedišča in razumevanjem besedil.

Marzano in Simms (2013) sta zbrala številne študije, ki dokazujejo, kako velik vpliv ima dobro poznavanje besedišča na razvoj ostalih jezikovnih zmožnosti in kako pomembno vlogo pri tem ima poučevanje besedišča. Marzano in Pickering (2005) predlagata šest korakov, s katerimi bo učenec usvojil akademsko besedišče, se pravi tisto besedišče, ki je bolj sofisticirano in ga potrebuje za doseganje npr. učnih ciljev pri drugih predmetih. Prvi korak predvideva, da učitelj ustrezno pojasni (razlaga, primer) novo besedišče, nato mora učenec pojasniti besedišče s svojimi besedami, tretji korak je nejezikovna upodobitev besedišča (slika, simbol, grafična upodobitev) in nato sledijo vaje, s pomočjo katerih učenec poglobi znanje o ciljnem besedišču. Peti korak predstavlja rabo besedišča pri sodelovalnem učenju, šesti korak pa učenje preko igre, s katero se ciljno besedišče utrdi. Graves (2006) za uspešno poučevanje besedišča predlaga štiri dejavnike, ki pomagajo učencem razvijati leksikalno zmožnost. To so: bogata in raznolika jezikovna izpostavljenost, poučevanje posameznih besed, poučevanje strategij za učenje besedišča in krepitev besednega zavedanja. Marzano (2010) učitelje opozarja tudi na pomen ugotavljanja učenčevega predznanja besedišča, grupiranja besed v semantične mreže, poučevanja preko primerjanja besedišča, analogije, klasifikacij, metafor in inovativnih iger, ki spodbujajo večkratno izpostavitev besedišču.

Raznovrstne strategije, ki jih učenci bolj ali manj uporabljajo za učenje besedišča, so strokovnjaki poskušali smiselno razvrstiti, zato v literaturi najdemo več poskusov taksonomij strategij za učenje besedišča. Nation (2001) ločuje aktivnosti, ki podpirajo odkrivanje pomena besede in aktivnosti, ki spodbujajo priklic besedišča. Za uspešno učenje besedišča in razvijanja vseh štirih jezikovnih zmožnosti identificira naslednje strategije: ugibanje pomena s pomočjo konteksta, ugotavljanje pomena iz sestavnih delov besede, ugotavljanje glede na besedno družino, uporaba slovarja, učenje z učnimi kartami, jezikovni koščki in kolokacije. Gu (2003) ločuje med kognitivnimi, metakognitivnimi, spominskimi in aktivacijskimi strategijami za učenje besedišča.

Pomemben prispevek na področju strategij za učenje besedišča je prinesel Schmitt (1997), ki je pri svoji taksonomiji izhajal iz klasifikacije Oxfordove. O njegovi taksonomiji je v slovenskem raziskovalnem prostoru že obširno pisala Šifrar Kalan (2008a, 2008b). Svojo klasifikacijo Schmitt opiše kot »dinamičen delovni inventar« (1997, 204), ki obsega predloge skupin in njim pripadajoče strategije. Na podlagi raziskave, ki je bila izvedena med japonskimi študenti o rabi in uporabnosti strategij, je v klasifikacijo vključil 58 različnih strategij, prepričan pa je, da bi lahko vključil še veliko drugih različic. V osnovi se Schmittove strategije delijo na družbene, spominske, kognitivne in metakognitivne, kot pri Oxfordovi, doda jim še določilne/samostojne strategije. Nadalje jih razvrsti še v dve skupini, in sicer strategije za odkrivanje pomena besed in strategije za utrjevanje besed. Družbene strategije vključujejo ugotavljanje pomena v komunikaciji s sogovorcem - učiteljem, 
sošolcem, skupino sošolcev ali naravnimi govorci. Spominske strategije spodbujajo pomnjenje s pomočjo navezave na že obstoječe znanje, podobo in drugo. Kognitivne strategije so podobne spominskim, so mehanske narave in vključujejo veliko mero ponavljanja. Metakognitivne strategije vključujejo nadzorovanje učenja in samoevalvacijo. Schmitt (1997) ugotavlja, da prihaja do velikih težav pri razvrščanju posameznih strategij v skupine, in da je omejitev na izključno eno skupino precej problematična (prav tam).

Na podlagi svoje klasifikacije je razvil samoevalvacijski vprašalnik, $s$ katerim je poskušal identificirati učne strategije za učenje besedišča in ugotavljati dejansko rabo učnih strategij.

\section{RAZISKAVA}

\subsection{Opis problema}

$\mathrm{Z}$ raziskavo smo želeli ugotoviti, ali učitelji nemščine $\mathrm{v}$ slovenskih gimnazijah $\mathrm{v}$ pouk vključujejo poučevanje učnih strategij za učenje besedišča in kako pogosto posamezne strategije posredujejo dijakom. Številne študije dokazujejo, da učenci, ki znajo uporabljati primerne učne strategije, dosegajo boljši učni uspeh (Marzano in Simms 2013). Pri tem pa je pomembno, da se z učnimi strategijami spoznajo dovolj zgodaj, saj je kasneje le težko spremeniti učne navade, prav tako pa je pomembno, da učne strategije sami v praksi preizkusijo (Pavičić Takač 2009). Tudi Učni načrt za nemščino (2008) poudarja pomen razvijanja učnih strategij, ki so nujne za uresničevanje načel vseživljenjskega učenja. Glede na to, da v raziskovalnem prostoru pogrešamo študije, ki bi se osredotočale na učiteljevo posredovanje učnih strategij in še zlasti na posredovanje strategij za učenje besedišča $v$ tujem jeziku, nas je zanimalo, kakšno je stanje pri nas.

\subsection{Metodologija}

\subsubsection{Vzorec}

Vzorec naše raziskave predstavlja 72 učiteljic nemščine, ki poučujejo v programu gimnazija v Sloveniji in so v celoti odgovorile na vprašalnik o poučevanju učnih strategij. Elektronsko povezavo na vprašalnik smo julija 2014 poslali na dvesto elektronskih naslovov učiteljev nemščine. Po 14 dnevih smo anketni vprašalnik zaprli, ga umaknili s spleta in obdelali podatke, ki jih predstavljamo v nadaljevanju.

\subsubsection{Pripomočki}

Podatke smo zbrali s spletnim anketnim vprašalnikom, ki obsega 37 navedenih strategij za učenje besedišča, kjer so učitelji na lestvici od 1 (nikoli) do 5 (zelo pogosto) ocenjevali, 
kako pogosto načrtno poučujejo omenjene učne strategije. Pri izdelavi vprašalnika smo se oprli na taksonomije strategij za učenje besedišča, ki sta jih izdelala Schmitt $(1997,2000)$ in Nation (2001). Pilotiranje vprašalnika smo izvedli na študijskem srečanju učiteljev nemščine leta 2011. Vprašalnik, v katerega smo vključili vse strategije po Schmittu (1997), smo morali nekoliko popraviti in skrajšati, saj se je izkazalo, da je preobsežen in da učitelji niso pripravljeni vložiti toliko časa za reševanje. Uporabljeni vprašalnik ustreza kriteriju zanesljivosti, Cronbachov koeficient znaša 0, 89.

\section{REZULTATI IN RAZPRAVA}

Anketiranci so na Likertovi lestvici od 1 (nikoli) do 5 (zelo pogosto) ocenili, kako pogosto pri pouku nemščine načrtno razvijajo navedene strategije za učenje besedišča. Vprašalnik smo analizirali tako, da smo izračunali povprečno vrednost in standardni odklon rabe za posamezno strategijo. V tabeli 1 prikazujemo, kako pogosto učitelji vključujejo posamezne strategije za učenje besedišča v pouk nemščine.

Tabela 1: Strategije za učenje besedišča glede na pogostost rabe

\begin{tabular}{|c|l|c|c|}
\hline Zap. št. & Strategija za učenje besedišča & $\begin{array}{c}\text { Povp. } \\
\text { vrednost }\end{array}$ & $\begin{array}{c}\text { Stand. } \\
\text { odklon }\end{array}$ \\
\hline 1 & učenje besede skupaj s sliko, ki uprizarja pomen besede & 3,71 & 0,99 \\
\hline 2 & $\begin{array}{l}\text { ustvarjanje lastne mentalne podobe besede za pomnjenje } \\
\text { pomena besede }\end{array}$ & 2,77 & 1,00 \\
\hline 3 & povezovanje besede z osebno izkušnjo & 3,34 & 0,73 \\
\hline 4 & razvrščati besede v kategorije glede na pomen, funkcije ... & 3,74 & 1,01 \\
\hline 5 & $\begin{array}{l}\text { učenje ciljne besede s sopomenkami in protipomenkami ciljne } \\
\text { besede }\end{array}$ & 3,74 & 0,89 \\
\hline 6 & ustvarjanje semantičnih mrež ciljne besede & 3,43 & 0,92 \\
\hline 7 & novo besedo uporabljati v stavkih & 4,06 & 0,87 \\
\hline 8 & $\begin{array}{l}\text { sestavljanje zgodbe, kjer si ciljne besede sledijo v določenem } \\
\text { zaporedju }\end{array}$ & 2,57 & 1,12 \\
\hline 9 & raba metode ključnih besed & 2,46 & 1,04 \\
\hline 10 & glasno ponavljanje besede & 3,06 & 1,19 \\
\hline 11 & večkratno prepisovanje besede & 1,97 & 1,01 \\
\hline 12 & ustvarjanje mentalne podobe zapisane besede & 2,51 & 0,95 \\
\hline 13 & parafraziranje pomena besede & 3,29 & 0,86 \\
\hline 14 & učiti se posamezne dele fraze in nato celotno frazo uporabljati \\
za pomnjenje posameznih besed & 2,51 & 0,95 \\
\hline 15 & raba gibov in kretenj ob učenju besede & 2,49 & 1,04 \\
\hline 16 & poslušanje posnetega seznama besed & 3,26 & 1,07 \\
\hline 17 & pisanje slovarčka besed & & \\
\hline
\end{tabular}




\begin{tabular}{|c|c|c|c|}
\hline Zap. št. & Strategija za učenje besedišča & $\begin{array}{l}\text { Povp. } \\
\text { vrednost }\end{array}$ & $\begin{array}{l}\text { Stand. } \\
\text { odklon }\end{array}$ \\
\hline 18 & $\begin{array}{l}\text { ignoriranje neznane besede, ki ni bistvena za razumevanje } \\
\text { odlomka }\end{array}$ & 3,20 & 1,05 \\
\hline 19 & $\begin{array}{l}\text { poskus analize neznane besede glede na besedne vrste pri } \\
\text { govorjenem besedilu }\end{array}$ & 2,37 & 0,94 \\
\hline 20 & $\begin{array}{l}\text { s pomočjo ostalih besed v stavku ali povedi ugotavljati pomen } \\
\text { neznane besede }\end{array}$ & 3,94 & 0,73 \\
\hline 21 & $\begin{array}{l}\text { ugotavljati povezanost stavka, ki vsebuje neznano besedo z } \\
\text { ostalimi stavki, povedmi, odlomkom }\end{array}$ & 3,49 & 0,82 \\
\hline 22 & sklepati na podlagi splošnega znanja in ugibati pomen besed & 3,69 & 0,68 \\
\hline 23 & $\begin{array}{l}\text { uporabljati mentalne podobe in znana dejstva za pomoč pri } \\
\text { pomnjenju novih besed }\end{array}$ & 3,34 & 0,87 \\
\hline 24 & sklepati o neznani besedi na podlagi celotnega besedila & 3,69 & 0,90 \\
\hline 25 & $\begin{array}{l}\text { zamenjati neznano besedo z domnevno pravim prevodom in } \\
\text { ugotavljati smiselnost povedi }\end{array}$ & 2,37 & 1,14 \\
\hline 26 & analizirati predpone in korene pri ugibanju pomena & 2,94 & 1,03 \\
\hline 27 & učenje najpogostejših predpon na pamet & 2,20 & 1,05 \\
\hline 28 & učenje z branjem časopisov, revij ... & 3,54 & 1,17 \\
\hline 29 & raba slovarja pri učenju besed & 3,40 & 0,69 \\
\hline 30 & $\begin{array}{l}\text { ugotavljati podobnosti in razlike pri napisani in izgovorjeni } \\
\text { besedi }\end{array}$ & 2,63 & 0,91 \\
\hline 31 & načrtno učenje seznama besed & 2,26 & 1,15 \\
\hline 32 & uporabljati besede $v$ avtentičnih situacijah & 4,17 & 0,82 \\
\hline 33 & samoocenjevalne lestvice & 2,54 & 1,09 \\
\hline 34 & raba mnemo tehnik za pomnjenje besed & 2,66 & 1,00 \\
\hline 35 & raba konkretnih objektov pri učenju besedišča & 3,11 & 0,87 \\
\hline 36 & razlaganje primerov, v katerih se je pojavila nova beseda & 3,34 & 0,84 \\
\hline 37 & sestavljanje povedi z novo besedo & 3,86 & 0,85 \\
\hline
\end{tabular}

Iz tabele 1 je razvidno, da učitelji nemščine poznajo vse navedene strategije in jih v razredu tudi poučujejo. Pridobljene rezultate smo nato še natančneje kategorizirali v skupine glede na pogostost. Kategorija z ocenami od 1 do 1,49 pomeni nikoli ne poučujem, 1,5 do 2,4 pomeni redko poučujem, 2,5 do 3,49 predstavlja občasno poučujem, kategorija z oceno 3,5 do 4,49 pomeni pogosto poučujem in kategorija z oceno med 4,5 do 5 zelo pogosto poučujem.

Odgovori učiteljev kažejo, da nobena izmed navedenih strategij ni bila ocenjena z oceno nižjo od 1,49, kar bi pomenilo, da strategije nikoli ne poučujejo. To pomeni, da se učitelji zavedajo pomena poučevanja strategij za učenje besedišča za razvoj sporazumevalne zmožnosti oziroma natančneje leksikalne zmožnosti v tujem jeziku. Nadalje kažejo rezultati, da 8 od navedenih strategij učitelji poučujejo redko, saj so bile navedene strategije ocenjene z ocenami med 1,5 do 2,49. V kategorijo z ocenami od 2,5 do 3,49- občasno 
poučujem, je bilo uvrščenih 19 navedenih strategij. 10 strategij je bilo ocenjenih z ocenami od 3,5 do 4,49, kar pomeni, da jih učitelji pogosto poučujejo. Nobene strategije izmed navedenih učitelji niso ocenili z višje od 4,5, kar bi pomenilo zelo pogosto poučevanje.

V nadaljevanju se podrobneje posvečamo posameznim kategorijam. Najprej prikazujemo strategije, ki jih učitelji redko poučujejo in dosegajo povprečno oceno od 1,5 do 2,49 (Tabela 2).

Tabela 2: Strategije za učenje besedišča, ki jih učitelji redko poučnjejo

\begin{tabular}{|c|l|c|c|}
\hline Zap. št. & Strategija za učenje besedišča & $\begin{array}{c}\text { Povp. } \\
\text { vrednost }\end{array}$ & $\begin{array}{c}\text { Stand. } \\
\text { odklon }\end{array}$ \\
\hline 16 & poslušanje posnetega seznama besed & 1,74 & 0,98 \\
\hline 11 & večkratno prepisovanje besede & 1,97 & 1,01 \\
\hline 27 & učenje najpogostejših predpon na pamet & 2,20 & 1,05 \\
\hline 31 & načrtno učenje seznama besed & 2,26 & 1,15 \\
\hline 19 & $\begin{array}{l}\text { poskus analize neznane besede glede na besedne vrste } \\
\text { pri govorjenem besedilu }\end{array}$ & 2,37 & 0,94 \\
\hline 25 & $\begin{array}{l}\text { zamenjati neznano besedo z domnevno pravim } \\
\text { prevodom in ugotavljati smiselnost povedi }\end{array}$ & 2,37 & 1,14 \\
\hline 9 & raba metode ključnih besed & 2,46 & 1,04 \\
\hline 15 & raba gibov in kretenj ob učenju besede & 2,49 & 1,04 \\
\hline
\end{tabular}

Zanimivo je, da so učitelji z nizkimi vrednostmi ocenili, kar nekaj strategij, ki so, kot je ugotavljal Schmitt (1997), najbolj razširjene in tudi med učenci najbolj priljubljene. Navedene strategije bi lahko uvrstili tudi med najstarejše oziroma tradicionalne strategije učenja tujega jezika. Pridobljeni rezultati kažejo, da se spremenjene paradigme poučevanja tujega jezika, ki je komunikacijsko naravnan, odražajo tudi v poučevanju učnih strategij. Učenje seznamov besed, prepisovanje besed ali prevajanje oziroma analiza besede glede na slovnične lastnosti, ki izvirajo iz slovnično-prevajalne metode, so sicer še vedno prisotne pri pouku nemščine, vendar jih učitelji le redko načrtno poučujejo. Najverjetneje so te strategije precej poznane in ukoreninjene in zato jim učitelji posebnega poudarka ne namenjajo. V večini gre za preproste učne strategije, ki slonijo na ponavljanju, memoriranju ali prevajanju besedišča. Med redko poučevanimi strategijami je tudi metoda ključnih besed, za katero nekatere raziskave kažejo, da je zelo uspešna (Sagarra in Alba 2006, Rodriguez in Sadoski 2000, Hulstijn 1997, Atkinson in Raugh 1975). Domnevamo, da je vzrok za to predvsem v kompleksnosti in specifičnosti te metode. Prav tako redko se pojavlja učenje besed s pomočjo gibov in kretenj, kar pa ni presenetljivo, saj metode, ki bi poudarjale pomen gibanja pri učenju pri pouku nemščine v srednjih šolah niso pogoste (Retelj 2014).

Največ strategij za učenje besedišča dosega vrednosti od 2,5 do 3,49 in jih učitelji poučujejo občasno. V večini primerov gre za kompleksnejše strategije, kjer je potrebno določeno slovnično predznanje kot npr. »analizirati predpone in korene pri ugibanju pomena« ali dobro poznavanje besedišča, ki omogoča sklepanje o pomenu iz konteksta, npr. 
»)ugotavljati povezanost stavka, ki vsebuje neznano besedo z ostalimi stavki, povedmi, odlomkom« ali »parafraziranje pomena besede«. Nekatere strategije, ki jih učitelji občasno poučujejo, so pri učenju tujega jezika že dolgo uveljavljene, npr. »glasno ponavljanje besede«, »pisanje slovarčka besed «, »raba slovarja pri učenju besed «, a so nekoliko zamudne in zahtevajo od dijakov večji časovni vložek. Sklepamo, da jih učitelji občasno ravno zaradi tega uvajajo v pouk. Občasno se učitelji posvečajo torej strategijam, ki se osredotočajo na usvajanje pomena besed, strategijam, ki spodbujajo pravilen zapis in izgovarjavo besede ter ozaveščajo slovnične lastnosti besede.

Tabela 3: Strategije za učenje besedišča, ki jib učitelji občasno pončnjejo

\begin{tabular}{|c|c|c|c|}
\hline Zap. št. & Strategija za učenje besedišča & $\begin{array}{l}\text { Povp. } \\
\text { vrednost }\end{array}$ & $\begin{array}{l}\text { Stand. } \\
\text { odklon }\end{array}$ \\
\hline 12 & ustvarjanje mentalne podobe zapisane besede & 2,51 & 0,95 \\
\hline 14 & $\begin{array}{l}\text { učiti se posamezne dele fraze in nato celotno frazo } \\
\text { uporabljati za pomnjenje posameznih besed }\end{array}$ & 2,51 & 0,95 \\
\hline 33 & samoocenjevalne lestvice & 2,54 & 1,09 \\
\hline 8 & $\begin{array}{l}\text { sestavljanje zgodbe, kjer si ciljne besede sledijo v določenem } \\
\text { zaporedju }\end{array}$ & 2,57 & 1,12 \\
\hline 30 & $\begin{array}{l}\text { ugotavljati podobnosti in razlike pri napisani in izgovorjeni } \\
\text { besedi }\end{array}$ & 2,63 & 0,91 \\
\hline 34 & raba mnemo tehnik za pomnjenje besed & 2,66 & 1,00 \\
\hline 2 & $\begin{array}{l}\text { ustvarjanje lastne mentalne podobe besede za pomnjenje } \\
\text { pomena besede }\end{array}$ & 2,77 & 1,00 \\
\hline 26 & analizirati predpone in korene pri ugibanju pomena & 2,94 & 1,03 \\
\hline 10 & glasno ponavljanje besede & 3,06 & 1,19 \\
\hline 35 & raba konkretnih objektov pri učenju besedišča & 3,11 & 0,87 \\
\hline 18 & $\begin{array}{l}\text { ignoriranje neznane besede, ki ni bistvena za razumevanje } \\
\text { odlomka }\end{array}$ & 3,20 & 1,05 \\
\hline 17 & pisanje slovarčka besed & 3,26 & 1,07 \\
\hline 13 & parafraziranje pomena besede & 3,29 & 0,86 \\
\hline 3 & povezovanje besede z osebno izkušnjo & 3,34 & 0,73 \\
\hline 36 & razlaganje primerov, v katerih se je pojavila nova beseda & 3,34 & 0,84 \\
\hline 23 & $\begin{array}{l}\text { uporabljati mentalne podobe in znana dejstva za pomoč pri } \\
\text { pomnjenju novih besed }\end{array}$ & 3,34 & 0,87 \\
\hline 29 & raba slovarja pri učenju besed & 3,40 & 0,69 \\
\hline 6 & ustvarjanje semantičnih mrež ciljne besede & 3,43 & 0,92 \\
\hline 21 & $\begin{array}{l}\text { ugotavljati povezanost stavka, ki vsebuje neznano besedo, z } \\
\text { ostalimi stavki, povedmi, odlomkom }\end{array}$ & 3,49 & 0,82 \\
\hline
\end{tabular}


$\mathrm{V}$ kategorijo pogosto poučevanih strategij smo razporedili 10 strategij, ki zavzemajo vrednosti od 3,5 do 4, 49. Zbrane so v tabeli 4.

Tabela 4: Strategije za učenje besedišča, ki jib učitelji pogosto poučujejo

\begin{tabular}{|c|l|c|c|}
\hline Zap. št. & Strategija za učenje besedišča & $\begin{array}{c}\text { Povp. } \\
\text { vrednost }\end{array}$ & $\begin{array}{c}\text { Stand. } \\
\text { odklon }\end{array}$ \\
\hline 28 & učenje z branjem časopisov, revij ... & 3,54 & 1,17 \\
\hline 22 & sklepati na podlagi splošnega znanja in ugibati pomen besed & 3,69 & 0,68 \\
\hline 24 & sklepati o neznani besedi na podlagi celotnega besedila & 3,69 & 0,90 \\
\hline 1 & učenje besede skupaj s sliko, ki uprizarja pomen besede & 3,71 & 0,99 \\
\hline 5 & $\begin{array}{l}\text { učenje ciljne besede s sopomenkami in protipomenkami ciljne } \\
\text { besede }\end{array}$ & 3,74 & 0,89 \\
\hline 4 & razvrščati besede v kategorije glede na pomen, funkcije ... & 3,74 & 1,01 \\
\hline 37 & sestavljanje povedi z novo besedo & 3,86 & 0,85 \\
\hline 20 & $\begin{array}{l}\text { s pomočjo ostalih besed v stavku ali povedi ugotavljati pomen } \\
\text { neznane besede }\end{array}$ & 3,94 & 0,73 \\
\hline 7 & novo besedo uporabljati v stavkih & 4,06 & 0,87 \\
\hline 32 & uporabljati besede v avtentičnih situacijah & 4,17 & 0,82 \\
\hline
\end{tabular}

Iz tabele 4 lahko razberemo, da gre predvsem za strategije, ki se navezujejo na učenje pomena besede bodisi izoliranega besedišča kot npr. učenje besede skupaj s sliko, ki ponazarja pomen besede, učenje ciljne besede s sopomenkami in protipomenkami ciljne besede, razvrščati besede v kategorije glede na pomen, funkcije ... bodisi besedišča v kontekstu, npr. s pomočjo ostalih besed v stavku ali povedi ugotavljati pomen neznane besede, sklepati o neznani besedi na podlagi celotnega besedila, sklepati na podlagi splošnega znanja in ugibati pomen besed. V to kategorijo so učitelji razvrstili tudi strategije za pravilno rabo besedišča, npr. novo besedo uporabljati v stavkih, uporabljati besede v avtentičnih situacijah.

$\mathrm{V}$ kategorijo zelo pogosto poučujem učitelji niso razvrstili nobene strategije. Sklepamo, da učitelji s časom, namenjenim poučevanju strategij za besedišče, dosegajo cilje, ki so si jih zastavili.

\section{ZAKLJUČEK}

Glavni cilj raziskave je bil ugotoviti, kako pogosto učitelji pri pouku nemščine razvijajo posamezne strategije za učenje besedišča in identificirati najbolj pogosto poučevane strategije. Izbrane strategije smo razvrstili v 5 kategorij: nikoli ne poučujem - od 1 do 1,49, redko роис̌ијеm od 1,5 do 2,49, оьс̌аsno роисиијет od 2,5 do 3,49, pogosto pouс̌ијет od 3,5 do 4,49 in zelo pogosto poučujem od 4,5 do 5.

Izkazalo se je, da so vse strategije pri poučevanju nemščine pri nas prisotne, saj nobena strategija ni bila ocenjena nižje od 1,49. Redko se pri pouku nemščine izpostavlja tiste 
strategije, ki jih učenci najverjetneje poznajo že iz drugih predmetov ali pa so zelo specifične. Pri izbiri slednjih najverjetneje prevlada učiteljevo poznavanje strategij in njegove lastne izkušnje. Največji del strategij učitelji vključujejo v pouk občasno. Sklepamo, da jih izbirajo glede na druge jezikovne cilje in trenutne cilje pouka.

Strategije, ki jih učitelji poučujejo pogosto, so ugotavljanje pomena besedišča s pomočjo konteksta, raba novega besedišča v stavkih in raba novega besedišča v avtentičnih situacijah. Ugotavljamo, da učitelji poučujejo kompleksnejše strategije za učenje besedišča, ki ga dijaki potrebujejo za razumevanje govorjenih in pisnih besedil in da poučujejo tudi strategije, s katerimi spodbujajo rabo novega besedišča pri lastni produkciji jezika. V kategorijo zelo pogosto poučujem ni bila uvrščena nobena strategija.

Čeprav zaradi majhnosti vzorca ne moremo popolnoma posplošiti naših ugotovitev, pa se vseeno kaže, da dijaki pri pouku nemščine v slovenskih gimnazijah spoznajo različne učne strategije za učenje besedišča, ki jih lahko izkoristijo tako za učenje tujih jezikov kot tudi za učenje neznane terminologije $v$ maternem jeziku.

$\mathrm{Z}$ našo raziskavo smo poskušali osvetliti stanje $\mathrm{z}$ vidika poučevanja strategij za učenje besedišča $v$ nemščini in hkrati odpreti poti za nadaljnja raziskovanja, ki bi dala odgovor na to, katere strategije za učenje nemškega besedišča pa današnji dijaki zares uporabljajo.

\section{LITERATURA}

ATKINSON, Richard C./Michael, R. RAUGH (1975) An application of the Mnemonic keyword method to the acquisition of a Russian Vocabulary. Journal of Experimental Psychology, 104 (2), 126-133.

CHAMOT, Anna (2009) The CALLA Handbook. Implementing the Cognitive Academic Language Learning Approach. New York: Pearson Education.

COHEN, Andrew (2007) Coming to terms with language learner strategies: Surveying the experts. A. Cohen in E. Macro (ur.), Language learning strategies: 30 years of research and practice. Oxford: OUP, 29-45.

GU, Peter Yongqi/Robert K. JOHNSON (1996) Vocabulary learning strategies and language learning out -comes. Language Learning 46(6), 643-679.

GRAVES, Michael F. (2006) The vocabulary book: Learning and instruction. New York: Teachers College Press.

HULSTIJN, Jan H. (1997) Mnemonic methods in foreign language vocabulary learning. J. Coady/T. Huckin (ur.), Second language vocabulary acquisition. Cambridge: CUP, 203-22.

LAH ŠUSTER, Anamarija (2013) Učenje tujega jezika v otroštvu - stopnja osebnostne razvitosti in razvitost strategij v 2. triadi Oš. Vestnik za tuje jezike letn. 5, št. 1/2, 95-113, doi: 10.4312/vestnik.5, 95-11.

LEE, Kyung (2003) The relationship of school year, sex and proficiency on the use of learning strategies in learning English. Asian EFL Journal 5(4), 1-36. 
MARZANO, Robert. J. (2010) Teaching basic and advanced vocabulary: A frameworkfor direct vocabulary instruction. Boston, MA: Heinle.

MARZANO, Robert. J./Debra PICKERING (2005) Building Academic Vocabulary Teacher's Manual. Alexandria, VA: ASCD.

MARZANO, Robert J./Julia, A. SIMMS (2013) Vocabulary fort he common core. Bloomington: Marzano Research Laboratory.

NATION, I. S. Paul (2001) Learning vocabulary in another language. Cambridge: CUP.

O’ MALLEY, J. Michael/Anna CHAMOT (1990) Learning strategies in second language acquisition. Cambridge: CUP.

O’MALLEY, J. Michael/Anna CHAMOT/Gloria STEWNER-MANZANARES/Lisa KUPPER/Rocco RUSSO (1985) Learning strategies used by beginning and intermediate ESL students. Language Learning 35(1), 21-46.

OXFORD, Rebecca (1990) Language learning strategies: What every teacher should know. Boston: Heinle \& Heinle.

OXFORD, Rebecca (2002) Language learning strategies in a nutshell: Updated ESL suggestions. J. C. Richards/A. W. Renadya (ur.), Methodology in languages teaching, An anthology of current practice. Cambridge: CUP, 124-132.

PARIBAKHT, Sima/Marjorie WESCHE (1997) Vocabulary enhancement activities and reading for meaning in second language vocabulary acquisition. J. Coady/T. Huckin (ur.), Second Language Vocabulary Acquisition. Cambridge: CUP, 174-200.

PAVIČIĆ TAKAČ, Višnja (2008) Vocabulary Learning Strategies and Foreign Language. Acquisition. Clevedon, UK: Multilingual Matters.

PRICHARD, Caleb (2008) Evaluating L2 readers' vocabulary strategies and dictionary use. Reading in Foreign Language 20(2), 216-223.

RETELJ, Andreja (2014) Pouk nemščine v gimnazijah skozi prizmo metod in pristopov k poučevanju. Vestnik za tuje jezike, letn. 6, št. 1, 221-234. doi: 10.4312/vestnik.6.221-234.

RODRIGUEZ, Maximo/Mark SADOSKI (2000) Effects of rote, context, keyword, and context/keyword methods on retention of vocabulary in EFL classrooms. Language Learning 50(2), 385-412.

RUBIN, Joan (1987) Learner strategies: Theoretical assumptions, research history and typology. V A. Wenden/J. Rubin (ur.), Learner strategies in language learning. Englewood, NJ: Prentice/Hall International, 15-30.

SAGARRA, Nuria/Matthew ALBA (2006) The key is in the keyword: L2 vocabulary learning methods with beginning learners of Spanish. The Modern Language Journal 90 (2), 228-243.

SCHMITT, Norbert (1997) Vocabulary learning strategies. N. Schmitt/M. McCarthy (ur.), Vocabulary: Description, acquisition and pedagogy. Cambridge: CUP, 199-227.

SCHMITT, Norbert (2000) Vocabulary in language teaching. Cambridge: CUP.

ŠIFRAR KALAN, Marjana (2008a) Učne strategije pri učenju tujega jezika. J. Skela (ur.), Učenje in poučevanje tujih jezikov na Slovenskem: pregled sodobne teorije in prakse. Ljubljana: Tangram, 30-50. 
ŠIFRAR KALAN, Marjana (2008b) Raziskovanje učnih strategij za usvajanje besedišča. J. Skela (ur.), Učenje in poučevanje tujih jezikov na Slovenskem: pregled sodobne teorije in prakse. Ljubljana: Tangram, 51-73.

TSENG, Wen-Ta/Zoltán DÖRNYEI/Norbert SCHMIT (2006) A New Approach to Assessing Strategic Learning: The Case of Self-Regulation in Vocabulary Acquisition. Applied Linguistiscs 27/1, 78-102.

JELENC, Zoran (2007) (ur.) Strategija vseživljenjskosti učenja v Sloveniji. Ljubljana: Ministrstvo za šolstvo in šport Republike Slovenije: Javni zavod Pedagoški inštitut. http://www.mss.gov.si/fileadmin/mss.gov.si/pageuploads/podrocje/razvoj_solstva/ IU2010/Strategija_VZU.pdf

\section{POVZETEK}

\section{Poučevanje strategij za učenje besedišča pri pouku nemščine v slovenskih gimnazijah}

V prispevku se osredotočamo na poučevanje strategij za učenje besedišča pri pouku nemščine v slovenskih gimnazijah. Zanimalo nas je, katere strategije za učenje besedišča učitelji nemščine v gimnazijah načrtno poučujejo in kako pogosto dijake z njimi seznanjajo. Spletni vprašalnik, ki temelji na Schmittovi (1997) in Nationovi (2001) taksonomiji in vsebuje 37 strategij za učenje besedišča, je rešilo 72 učiteljev nemščine. Rezultati raziskave kažejo, da so pri pouku nemščine prisotne vse strategije za učenje besedišča. Učitelji najpogosteje poučujejo 10 strategij, 19 strategij vključujejo občasno in 8 redko. Zelo pogosto ne poučujejo nobene strategije. Pri pouku pogosto poučujejo strategije, ki spodbujajo učenje pomena besede iz konteksta in ugibanje pomena ter aktivno rabo besedišča, občasno pa tudi strategije, ki obsegajo ostale vidike. Redko se posvečajo strategijam za memoriranje besed. Ugotavljamo, da učitelji nemščine z vključevanjem strategij za učenje besedišča prispevajo k učenčevi samostojnosti pri učenju nemščine in posredno pri učenju drugih tujih jezikov.

Ključne besede: strategije za učenje besedišča, poučevanje učnih strategij, razvijanje leksikalne zmožnosti, srednja šola, nemščina

\section{ABSTRACT}

\section{Teaching Vocabulary Learning Strategies in German as a Foreign Language Class in Slove- nian High Schools}

The aim of the study was to find out the type and the frequency of vocabulary learning strategies that German language teachers teach in their classes. An online questionnaire which included 37 vocabulary learning strategies based on Schmitt's (1997) and Nation's (2001) taxonomies was administered to 72 German teachers. The results revealed that all vocabulary learning strategies were instructed in German as foreign language lessons in Slovenia; however, 10 strategies were instructed often, 19 strategies occasionally and 8 strategies rarely. None of the strategies were instructed very often. The strategies that teachers often taught in their classes included learning the meaning from context, 
guessing and active use of words. The strategies that were occasionally instructed cover also other aspects of word knowledge. Strategies that promote memorization of words were rarely instructed. We can conclude that German teachers with the deliberate instruction of vocabulary learning strategies contribute to learners' autonomy in learning German language and indirectly in further learning of foreign languages.

Key words: vocabulary learning strategies, teaching vocabulary learning strategies, development of lexical competence, secondary school, German as a foreign language 